\title{
Making Intramilitary Tort Law More Civil: A Proposed Reform of the Feres Doctrine
}

\section{David Saul Schwartz}

Under Feres $v$. United States, ${ }^{1}$ the government and its military officials are immune from tort claims by military personnel for harms arising out of military service. The Feres doctrine began as a reasonable rule: The government could not be sued, under 50 different state-law rules, for accidental injuries to soldiers who were already covered by military benefits. But since 1950 the Feres doctrine has grown into something quite different from the original rule. A list of the various claims barred today by the Feres doctrine illustrates: black servicemen claiming racially discriminatory punishments and duty assignments by a superior officer; ${ }^{2}$ a servicewoman claiming to have been sexually assaulted by a superior; ${ }^{3}$ an army intelligence agent found dead after allegedly being confined and interrogated for nine days by Army and CIA agents who had learned of his intention to write his memoirs; ${ }^{4}$ soldiers subjected to experimental injections of $\mathrm{LSD}^{\circ}$ thousands of soldiers ordered to participate in atomic radiation experiments. ${ }^{\circ}$ If this is the necessary outcome of the rule, it no longer appears so reasonable. Rather, it seems to say that the military has the power of life and death over its personnel, with no limit recognized in the constitution or a tort claim.

The courts cannot mean that the military has such far-reaching authority; instead, the implicit rationale for the Feres doctrine is the belief that intramilitary procedures can perform the public tort law functions of compensation and deterrence, while protecting the military's interest in maintaining discipline, far more effectively than federal courts can. In this note I argue that, in fact, the military remedies do not adequately deter, or even compensate for, egregious military misconduct. I then propose replacing the overly restrictive Feres doctrine with a general rule of al-

\footnotetext{
1. 340 U.S. 135 (1950).

2. See Chappell v. Wallace, 462 U.S. 296 (1983).

3. See Stubbs v. United States, 744 F.2d 58 (11th Cir. 1984).

4. See Sigler v. LeVan, 485 F. Supp. 185 (D. Md. 1980).

5. See Stanley v. CIA, 639 F.2d 1146 (5th Cir. 1981); Thornwell v. United States, 471 F. Supp. 344 (D.D.C. 1979).

6. See, e.g., Jaffee v. United States, 663 F.2d 1226 (3rd Cir. 1980) (en banc), cert. denied, 457 U.S. 1133 (1982).
} 
lowing intentional or constitutional tort claims by former servicemen or their families. This proposal would permit the claims against more serious misconduct to go forward, while still showing a measure of deference to the military's internal remedies and to its need for discipline.

\section{Military Remedies as Part of a System of Public Tort LAW}

Despite the Feres doctrine's bar of all intramilitary tort claims, the underlying rationale suggests a theory of public tort law that recognizes that the soldier's relationship to the military may give rise to tort liability. However, the military's system of remedies cannot fully compensate victims and deter perpetrators of egregious misconduct.

\section{A. The Feres Doctrine}

The Feres doctrine forecloses the two avenues by which citizens can sue the government. ${ }^{7}$ Feres $v$. United States ${ }^{8}$ held that the federal government was not liable under the Federal Tort Claims Act ("FTCA") for injuries to servicemen "arising out of or in the course of military duty." The Court relied predominantly on three considerations in reaching its result. First, the purpose of the FTCA was not to create new causes of action, but to make the United States liable "in the same manner and to the same extent as private individuals under like circumstances."10 Because, according to the Court, there was no pre-existing American law of intramilitary negligence, the FTCA should not be construed to create it. ${ }^{11}$ Second, be-

7. First, plaintiffs alleging tortious conduct violating constitutional rights have recourse to remedies implied directly under the constitution. Bivens v. Six Unknown Named Agents, 403 U.S. 388 (1971). Bivens claims are brought directly against individual officials, who are protected by official immunity, but not sovereign immunity. Second, suits can be brought against the government under the Federal Tort Claims Act ("FTCA"), which waives sovereign immunity. 60 Stat. 842 (1946) (codified in scattered sections of 28 U.S.C.). See infra note 69.

8. 340 U.S. 135 (1950). Feres involved a suit for negligence by the wife of a serviceman who was killed when his barracks burned down. The Court, in hearing the case, consolidated it with two medical malpractice cases by servicemen against their army doctors, Jefferson v. United States, 178 F.2d 518 (4th Cir. 1949), and Griggs v. United States, 178 F.2d 1 (10th Cir. 1949).

9. 340 U.S. at 146. But see Brooks v. United States, 337 U.S. 49 (1949) (allowing FTCA recovery by two enlisted men injured while on furlough when military truck collided with their car on public highway, because injuries not "incident to service"). See also United States v. Brown, 348 U.S. 110 (1954) (former serviceman allowed to sue United States for post-discharge negligence of Army doctors). The tension between Brooks and Brown, on the one hand, and Feres, on the other, has created some anomalous results. See Molsbergen v. United States, 757 F.2d 1016 (9th Cir. 1985) (government liable for failure to warn servicemen of radiation exposure after discharge, though not liable if failure to warn occurred prior to discharge from service); Thornwell v. United States, $471 \mathrm{~F}$. Supp. 344 (D.D.C. 1979) (military held liable for post-discharge negligent failure to treat ex-soldier known to have been given experimental doses of $\mathrm{LSD}$, though not liable for tort of administering LSD to begin with), and cases discussed infra note 90.

10. 340 U.S. at 141 (quoting FTCA, 28 U.S.C. § 2674 (1982)).

11. Since Feres, the Court has held the federal government liable under the FTCA for negligent 
cause the FTCA adopted "the law of the place where the act or omission occurred," the federal government's liability would be subject to various standards. Since the relationship between the government and its servicemen is "distinctively federal in character"12 - it is governed by federal law, and the stationing of servicemen in the several states is random-the Court believed that "[i]t would hardly be a rational plan" for Congress to subject the government to various state standards of liability to military personnel "dependent upon geographic considerations." istence of a "simple, certain and uniform compensation scheme for injuries or death of those in the armed services" made additional FTCA recovery inappropriate. ${ }^{14}$

More recently, the Feres doctrine has been expanded to bar intentional and constitutional tort claims against individual officials. In Jaffee $v$. United States, ${ }^{15}$ former servicemen sued the government and various civilian and military officials, alleging that their exposure to radiation from their participation in training maneuvers at nuclear testing $\operatorname{sites}^{16}$ caused

conduct of activities in which private persons do not or cannot engage. See United States v. Muniz, 374 U.S. 150 (1963) (federal prison officials); Rayonier, Inc. v. United States, 352 U.S. 315 (1957) (government firefighters); Indian Towing Co. v. United States, 350 U.S. 61 (1955) (coast guard lighthouse operation).

12. 340 U.S. at 143 (quoting United States v. Standard Oil Co., 332 U.S. 301 (1947)).

13. 340 U.S. at 143 .

14. Id. at 144-45. Feres did not discuss the issue of military discipline, even though such concerns had been raised by the court of appeals in one of the companion cases to Feres. See Jefferson v. United States, 178 F.2d 518, 520 (4th Cir. 1949). The Supreme Court later read the discipline rationale into the Feres decision in United States v. Brown, 348 U.S. 110, 112 (1954) (emphasizing "peculiar and special relationship of the soldier to his superiors, the effects of the maintenance of such suits on discipline, and the extreme results that might obtain if suits . . were allowed for negligent orders given or negligent acts committed in the course of military duty"), and Stencel Aero Engineering Corp. v. United States, 431 U.S. 666, 673 (1977) (prospect of "second-guessing military orders" and requiring "members of the Armed Services to testify in court as to each other's decisions and actions" weighed against claim by manufacturer for indemnity against United States under FTCA in connection with injury of National Guard pilot whose plane had malfunctioned).

15. 663 F.2d 1226 (3rd Cir. 1980) (en banc), cert. denied, 457 U.S. 1133 (1982).

16. Jaffee was the leading case arising out of a series of on-ground nuclear weapons tests conducted by the Atomic Energy Commission ("AEC") and the military. Between 1945 and 1962, an estimated 250,000 United States military personnel were exposed to large doses of radiation while participating in maneuvers designed to determine the effectiveness of combat troops in nuclear battlefield conditions. Veterans' Claims for Disabilities from Nuclear Weapons Testing: Hearing Before the Senate Comm. on Veterans Affairs, 96th Cong., 1st Sess. (1979) [hereinafter cited as Veterans Exposure Hearing]; Favish, Radiation Injury and the Atomic Veteran: Shifting the Burden of Proof on Factual Causation, 32 Hastings L.J. 933 (1981); Hughe \& Konigsburg, Grim Legacy of Nuclear Testing, N.Y. Times, Apr. 22, 1979, § 6 (Magazine), at 34. For a particularly gripping account, see T. SAFFer \& O. Kelly, Countdown Zero: GI Victims of U.S. Atomic Testing (1982).

Soldiers were typically positioned one to three miles from nuclear detonations ranging from ten kilotons to one megaton. In many cases, soldiers would approach ground zero within minutes or hours of detonation. They were issued no protective equipment (as were AEC civilian personnel), and were not warned as to the possible dangers of radiation. They were typically instructed to cover their eyes with their forearms at detonation. According to first-hand accounts, soldiers with their eyes shut could see the bones in their forearms at the moment of the explosion. See T. SAFFER \& O. KELLEY, supra, at $43,75,152$. 
severe, long-term injuries to themselves and their families. ${ }^{17}$ The plaintiffs claimed intentional misconduct on the part of the military, not mere negligence as in Feres. ${ }^{18}$ Their arguments were based in part on the premise that the military does not have the authority to command its soldiers to act as subjects in an experiment on the effects of radiation. But the courts in Jaffee and similar cases have rejected these arguments and held that the Feres rationale applies whether the defendant is an individual or the government, whether the injury was merely negligent or intentional, and whether a constitutional violation may have occurred or not. ${ }^{19}$ These decisions have emphasized the Feres court's belief that the existence of a compensation scheme for military injuries obviated the need for additional tort recovery, but they have also relied a great deal on a concern for military discipline. $^{20}$

Although the Supreme Court has not ruled on any of the "Atomic Veterans" cases, it did employ the Feres doctrine to dismiss a constitutional tort claim in which black sailors alleged injurious racial discrimination by their superior officers. In Chappell $v$. Wallace, ${ }^{21}$ the Court held broadly

17. The servicemen themselves have suffered from inoperable cancer and leukemia, as well as a variety of non-malignant disorders, all of which have occurred in disporportionate numbers for the victims' age cohort. The litigation has also included claims by surviving family members, see, e.g., Laswell v. Brown, 683 F.2d 261 (8th Cir. 1982), cert. denied, 459 U.S. 1210 (1983) (barring survivors' cause of action for injury to serviceman which was itself barred by Feres), and claims by wives and children alleging that genetic damage from the radiation caused miscarriages and birth defects. See, e.g., Hinkie v. United States, 715 F.2d 96, 97 (3rd Cir. 1983) (claims barred under Feres because they were "derivative" of or had their "genesis" in the intramilitary tort); Lombard v. United States, 690 F.2d 215, 223 (D.C. Cir. 1982) (same); Monaco v. United States, 661 F.2d 129, 133 (9th Cir. 1981), cert. denied, 456 U.S. 989 (1982) (same); see generally Note, The Feres Doctrine: Should it Apply to Atomic Veterans' Children?, 16 IND. L. REv. 753 (1983). Plaintiffs have also alleged that inadequate follow-up treatment or failure to warn victims of their potential injuries constituted separate, post-discharge torts. See infra note 90.

18. Arguably, the Feres opinion recognized that intramilitary intentional torts were a separate class of cases from negligence claims; and that, unlike intramilitary negligence, there was precedent for allowing soldiers to recover damages against their superiors for intentional injuries. See 340 U.S. at 141 n.10 (citing Dinsman v. Wilkes, 53 U.S. (12 How.) 390 (1851) (allowing seaman to recover from superior for assault and false imprisonment in course of naval mission)).

The Supreme Court has never decided whether Feres would bar intentional torts under the FTCA, probably because the FTCA did not make the United States liable for intentional torts until the 1974 amendments, Pub. L. No. 93-253, 88 Stat. 50 (1974) (codified at 28 U.S.C. $\S 2680(\mathrm{~h})(1982)$ ), and then only for intentional torts of law-enforcement officials. But cf. Chappell v. Wallace, 462 U.S. 296 (1983) (Feres rationale precludes creation of intramilitary damage action for constitutional tort). 17.

19. See, e.g., Gaspard v. United States, 713 F.2d 1097 (5th Cir. 1983) and cases cited supra note

20. A Bivens remedy is precluded by the existence of "an alternative remedy which [Congress] explicitly declared to be a substitute for recovery directly under the constitution and viewed as equally effective," Carlson v. Green, 446 U.S. 14, 18-19 (1980) (emphasis in original), or of "special factors counselling hesitation," Bivens, 403 U.S. at 396; Carlson v. Green, 446 U.S. at 19; Davis v. Passman, 442 U.S. 228, 246 (1979). The courts' expansive power to create a Bivens remedy was restricted by Bush v. Lucas, 462 U.S. 367 (1983) (though not necessarily "equally effective," civil service remedies were adequate substitute for Bivens remedy for alleged First Amendment violation by government employers, despite lack of explicit congressional declaration to that effect).

21. 462 U.S. 296 (1983). The plaintiffs, Wallace and four other black sailors, alleged that the 
that military personnel may not maintain damage suits against their superiors for alleged constitutional violations. Purporting to rely on Feres for guidance, the Chappell court found that " $[\mathrm{t}] \mathrm{he}$ need for special regulations in relation to military discipline, and the consequent need and justification for a special and exclusive system of military justice," as well as the need to condition the rights of soldiers "to meet certain overriding demands of discipline and duty," precluded the recognition of a constitutional tort action by military personnel against their superiors. ${ }^{22}$

None of the cases in the Feres line successfully articulates a clear and consistent rationale for barring these suits. Most refer to the existence of the military compensation scheme regardless of whether the particular plaintiff was actually eligible for compensation. The cases after Feres rely on the deleterious effect on discipline of allowing suits against superior officers or the government, but do not explain what that discipline consists of, why it is so important, or how it would be affected by such suits. Finally, the more recent cases, beginning with Chappell, rely on internal channels through which the military disciplines its own members, without inquiring whether those remedies are competent to address the issues raised when the military violates civilian norms. Viewed in their most coherent light, the Feres doctrine cases seem to stand for the proposition that the balance between soldiers' personal rights and military "discipline" is best achieved by the schemes of compensation and justice already existing within the military establishment. ${ }^{23}$ The problem with the Feres

captain and junior officers on their ship had given them punitive work details, unjustified punishments and poor performance ratings, and that these officers also failed to investigate incidents of racial harrassment, such as the scrawling of KKK graffiti on the bulkheads and work areas. Brief for Respondent at 2-3.

22. 462 U.S. at 300 . Chappell interpreted the "distinctively federal" character of intramilitary relations, Feres, 340 U.S. at 143, to mean "the unique relationship between the Government and military personnel." Chappell, 462 U.S. at 299 (emphasis added). In doing so, the Court seems to have shifted emphasis from one of the the rationales in Feres-a concern about various state-law liability standards-to a concern for military discipline. This shift in emphasis is not surprising, since the concern about various state-law negligence standards is obviated in the context of a Bivens claim, which implicates a uniform federal common law.

23. Chappell and Bush v. Lucas, 462 U.S. 367, were decided the same day. Taken together, they seem to indicate an effort to preclude Bivens remedies where the plaintiff is a federal employee and adequate alternative complaint procedures exist. See supra note 20 . Yet it is a mistake to read the sweep of these cases too broadly. The plaintiff in Bush was fired in retaliation for exercising what he believed to be his First Amendment rights, and the complaint procedure deemed adequate in Bush was an administrative review system explicitly designed to deal with personnel actions. Whatever one might think of an administrative tribunal's competence to decide First Amendment questions, it is significant that the plaintiff won his administrative appeal and was awarded reinstatement with back pay. 462 U.S. at 371 . The Court noted that $47 \%$ of those who appealed demotions and $24 \%$ of those who contested removal succeeded before the Civil Service Commission. Id. at 386 n.29. The complaint procedure in Bush, then, appeared meaningful and well-tailored to the complaint. Arguably, the complaint in Chappell, too, comes under the rubric of a personnel action. However well-tailored the military complaint procedure may be to deal with "personnel" problems, though, it is probably not well-suited to resolve tort claims (and perhaps not racial discrimination claims either). See supra notes 38-41 and accompanying text. 
doctrine, however, is that it sweeps too many qualitatively distinct tort claims under its bar, without regard for the actual adequacy of intramilitary remedies to resolve a particular claim.

\section{B. Feres and Public Tort Law}

Public tort law ${ }^{24}$ attempts to encourage vigorous conduct of governmental activities while compensating victims of those activities and deterring wrongful conduct by officials. ${ }^{25}$ These tort law functions should be implemented in a way that preserves institutional competence. ${ }^{26}$ Indeed, the Feres doctrine arguably reflects the belief of federal courts that military remedies have greater competence to resolve intramilitary tort questions.

At first glance, the relationship of soldiers to the military appears to be one that would not give rise to tort liability. The military is assigned the unique and special mission of defending the nation through combat. To perform this function, it is granted a degree of authoritarian control over its personnel that our liberal democratic state may not typically exercise over law-abiding citizens. In particular, military authorities are empowered to impose a high risk of serious physical harm on troops by ordering them into combat. The discipline underlying effective military force is thought to require restrictions on soldiers' personal freedom and acceptance of a certain degree of physical harshness and brutality in their living environment. In sum, the military enterprise appears to stand above other governmental activities in both the incidence of harm to its personnel and the diminution of the rights of those personnel.

24. Public tort law is a system of rights and remedies for citizens who have been harmed by the activity of government officials. Tort law, public or private, has been conceived of as a system for distributing the costs of activities that are socially necessary or desirable, while reinforcing social norms by deterring conduct deemed wrongful. See G. CAlabresi, The Costs of Accidents: A LEGAL AND ECONOMIC ANALYSIS 35-129 (1970). Where activities are socially desirable but inevitably cause some injuries, tort compensation provides a way of restoring the victim somewhat while assessing the accident cost to the tortfeasor's activity. This "general" or "market" deterrence is a way of insuring that accident costs are counted into activities and affect the amount or degree to which that activity will be conducted. See id. at 69 . Where an activity violates a moral norm, it is singled out for "specific" deterrence, meaning that it is made subject to penalties intended by society to carry the message that the activity should not be conducted, even if the actor is willing to bear additional costs to conduct it. See id. at 97 . Specific deterrence remedies may include declaratory judgments, punitive damage awards, or injunctions.

25. See P. Schuck, Suing Government: Cittzen Remedies for Official Wrongs 16-25 (1983).

26. Id. at 16, 23-24. "Institutional competence" refers to the resolution of remedial claims by the institution that has sufficient authority, power, information and legitimacy to implement the remedy effectively-in a way that optimally balances the conflicting goals of public tort law. For example, a civilian court's deference to intramilitary remedial procedures on the ground that the military "knows" more about the requirements of discipline reflects a particular view of institutional competence. On the other hand, this Note argues that civilian courts are a more "legitimate," and thus "institutionally competent," forum for impartial resolution of claims against the military in which societal norms are to be vindicated. 
Yet for the purposes of tort analysis, those are differences in degree and not in kind. In other forms of socially necessary work, both in government and the private sector, agents and third parties are routinely put in highrisk situations, and compensation schemes are implemented in anticipation of casualties. 27

The soldier's relationship to the military organization is not of so special a character that no tort liability arises from it. Rather, the military relies on a no-fault compensation scheme for injuries incurred by soldiers in the course of their military duties. ${ }^{28}$ This scheme represents a recognition that military activity is routinely hazardous but at the same time socially necessary. ${ }^{2 \theta}$ No-fault recovery that compensates according to a fixed schedule based on degree of (rather than circumstances surrounding) injury holds down transaction costs by obviating the need for extensive fault inquiry $^{30}$ and makes recoveries regular. This system thus rationalizes the costs of accidental harms within the military; it should not be taken to imply an absolute license of military commanders to inflict harm on military personnel. Unless we are prepared to concede that the military's authority to order soldiers into combat implies a power of life and death over military personnel in all situations, then we must recognize - as even military law does-that there are normative limits to the circumstances under which the military may inflict injuries on its personnel. The question then becomes which institution should determine what those limits are.

27. See, e.g. Longshoremen's and Harbor Workers' Compensation Act $\S 5,33$ U.S.C. $\S$ 905(a) (1982) (providing for exclusivity of compensation); Federal Employees Compensation Act $\S 1(56), 5$ U.S.C. \$ 8116 (1982) (exclusivity provision). See also Friedman \& Ladinsky, Social Change and the Law of Industrial Accidents, 67 ColuM. L. REv. 50, 71 (1967) ("rational, actuarial" workmen's compensation scheme, with limited recovery, replaced unpredictable fault or negligence system).

In law enforcement, firefighting, and coal mining, for example, a high degree of occupational risk seems to go along with a special need for esprit de corps and discipline among co-workers. See $\mathbf{M}$. WALZER, SPHERES OF Justice 169-70 (1983) (discussing this phenomenon in coal mining).

28. The Veterans' Benefits Act, 38 U.S.C. $\$ \S 314,322,334,342$ (1976), provides fixed rates of compensation based on degree of injury; the rates are the same for wartime and peacetime injuries. Active-duty members of the armed forces are eligible for free medical care. 10 U.S.C. $\$ \$ 1071-78$.

29. Thus, in Stencel Aero Engineering Corp. v. United States, 431 U.S. 666, 673 (1977), the Court found that the purpose of the Veterans' Benefits Act was to provide "swift, efficient" compensation and to place an upper limit on government liability. The Supreme Court has hinted in dicta that it would regard the Veterans' Benefits Act as an exclusive remedy, like other workmen's compensation schemes. See Hatzlachh Supply Co. v. United States, 444 U.S. 460, 464 (1980) (per curiam) (interpreting Stencel as finding veterans' benefits to be exclusive remedy for injured service members). Presumably, such a holding would require the Court to overrule the Brooks and Brown exceptions to the Feres doctrine, see supra note 9, and the Court seems to have backed away from this view. See Lockheed Aircraft Corp. v. United States, 460 U.S. 190, 197 n.8 (1983) (In Stencel, "we held that the [Feres] doctrine . . precluded the substantive claim without regard to any exclusive-liability provision.").

30. Veterans' benefit claims are often resolved on the basis of written claim forms submitted to local review boards. A claimant, upon request, can be provided an informal, ex parte hearing that inquires primarily into 1) the extent of injury and 2) whether the injury is service-connected. See Waiters v. National Ass'n of Radiation Survivors, 105 S. Ct. 3180,3183 (1985); 38 C.F.R. §§ 3.103(a), (c) (1985). 


\section{Inadequacies in the Intramilitary Remedial System}

The military establishment contains a remedial system that compensates its personnel for service-connected injuries ${ }^{31}$ and deters wrongful conduct by providing for punishments ${ }^{32}$ and a grievance procedure ${ }^{33}$ Thus, in principle, the citizen tort-victim's right to initiate a judicial remedial process is to some extent replicated for soldier tort-victims by intramilitary remedies.

In practice, however, institutional pressures cause the military remedial system to break down in precisely the cases where deterrence and compensation are most needed. As instruments of military policy, the remedial system cannot be relied upon to play a watchdog role, where that may cause embarrassment to the military; instead, the remedial system may be more likely to cover up military wrongdoing. ${ }^{34}$

31. See supra note 28.

32. The Uniform Code of Military Justice ("UCMJ"), 10 U.S.C. $\$ \S 801-940$ (1982) establishes the following court-martial offenses: Art. 93 ("cruelty toward, or oppression or maltreatment of, any person subject to [one's] orders"); Art. 97 (unlawful detention); Art. 118 (murder); Art. 128 (assault). 10 U.S.C. $\$ \S 893,897,918,928$ (1982).

33. UCMJ Art. 138, 10 U.S.C. § 938 (1982) provides:

Any member of the armed forces who believes himself wronged by his commanding officer, and who, upon due application to that commanding officer, is refused redress, may complain to any superior commissioned officer, who shall forward the complaint to the officer exercising general court-martial jurisdiction over the officer against whom it is made. The officer exercising general court-martial jurisdiction shall examine into the complaint and take proper measures for redressing the wrong complained of; and he shall, as soon as possible, send to the Secretary concerned a true statement of that complaint, with the proceedings had thereon. The Chappell court identified Art. 138 as the soldier's chief remedy against official abuse. See 462 U.S. at 302-03.

34. The Jaffee situation, see supra note 16, shows all too clearly how even the seemingly noncontroversial issue of compensation can become an instrument of military policy. To this day, the military establishment has refused to acknowledge that it did anything to harm the Atomic Veterans. See, e.g., N.Y. Times, Oct. 3, 1981, at 15, col. 1 (Reagan administration opposed Senate bill to give priority to Atomic Veterans' claims before VA, on grounds that it creates "the mistaken impression" that "exposure to low-level ionizing radiation is a significant health hazard"). Compare Veterans Exposure Hearing, supra note 16, at 29-30 (statement of Lt. Gen. Harry A. Griffith, Director, Defense Nuclear Agency) ("no credible data showing a correlation between exposure to extremely low levels of radiation, such as that experienced by the veterans, and any adverse long term health effects") with Favish, supra note 16, at 949-51 (Army records systematically underestimated radiation exposure by failing to take readings from all participants, failing to measure three of four forms of radiation, and failing to monitor radiation inhaled or ingested). See also Review of the Dept. of Energy's Health and Mortality Study: Hearing Before the Subcomm. on Investigations and Oversight of the House Comm. on Science and Technology, 97th Cong., 2d Sess. 150 (1982) (statement of Robert Alvarez, Washington Rep., Environmental Policy Center) (control by Deptartment of Energy of more than $60 \%$ of all federal research on radiation health effects is "fundamental conflict of interest [that] has created a record of suppression and distortion of science").

From the 1950s to the present, the military's response to the Atomic Veterans has been to cover up rather than to remedy their problems. Despite official assurances at the time that radiation doses were too low to cause harm, the documentary record shows a legacy of accidents, suppressed warnings and unfavorable scientific studies, and manipulation of radiation readings taken from test sites and from individual troops. See H. BALL, Justice Downwind: AMERICA's Atomic Testing Program in THE 1950 s 198 (1986). For many of the 250,000 servicemen who participated, official records, including radiation readings taken from the men at the time, were destroyed by fire at a federal records center in St. Louis. See T. SAFFER \& O. KELLY, supra note 16, at 145; Favish, supra note 16, at 
The military justice system is probably competent to punish and deter isolated misconduct of lower level officers ${ }^{36}$ that sharply departs from the military's own norms of behavior. ${ }^{36}$ But it may be less competent to deter conduct that is part of a widespread problem. For example, racial and sexual harrassment-widespread problems in the military no less than in civilian society-have given rise to lawsuits in which the plaintiffs have alleged that effective intramilitary redress was unavailable. ${ }^{37}$ Nor do mili-

956-57. See also Veterans Exposure Hearings, supra note 16, at 19 (radiation dose data for at least $38 \%$ of 250,000 test participants must be "reconstructed"). This and other documentation, which the Departments of Energy (successor to the AEC) and Defense have been resistant to delivering to individual servicemen and Atomic Veterans' groups, is required by the Veterans Administration to prove eligibility for disability benefits.

The VA's grudging attitude toward granting disability benefits has been consistent with the government's implicit denial of liability. In VA claims, "reasonable doubt" regarding the service origin of injury and degree of disability is to be resolved in the claimant's favor, but the claimant has the burden "to submit evidence sufficient to justify a belief . . . that his claim is well-grounded." 38 C.F.R. $\$ 3.102$ (1985). This evidentiary burden has been extremely difficult for radiation-exposure claimants, due to the inaccurate radiation measurements made at the time and the subsequent loss of records. Regulations promulgated by the VA director in late 1983 require the VA to concede a claimant's participation in nuclear tests and a certain level of radiation exposure reconstructed from Army records, where a claimant's records cannot be found by the VA. 38 C.F.R. $\$ 3.311$ (1985). Nevertheless, the VA still retains a good deal of discretion to find that a claimant's radiation-induced injuries are not service-related. Legislative efforts to require the VA to presume service origin of all cancer cases among Atomic Veterans have proved unavailing. See infra note 71. Atomic Veterans have suffered from a broad range of illnesses, in disproportionate numbers for their age cohorts, but the VA refuses to recognize non-cancerous diseases as being linked to radiation exposure, despite new medical knowledge to the contrary. See Veterans Exposure Hearings, supra note 16, at 290, 293, 303 (statement of John Smitherman, Pres., Nat. Ass'n of Atomic Veterans). Only 15 out of 3,050 veterans claiming injuries from atomic-testing radiation exposure have received compensation. See Table dated Sep. 3, 1985, furnished by Alvin M. Guttman, Legislative Counsel, Nat. Ass'n of Atomic Veterans (on file with the author). For an account of one veteran's eventually successful six-year struggle for VA compensation, see T. SAFFER \& O. KeLLY, supra note 16, at 149-200.

Many ex-servicemen are probably deterred by the time and expense of gathering expert medical opinions to present to VA hearing boards; moreover, the VA is authorized to pay, and attorneys are allowed to accept, only ten dollars in attorneys' fees of a successful claimant. 38 U.S.C. $\$ \S 3404-05$ (1982); see Walters v. National Ass'n of Radiation Survivors, 105 S. Ct. 3180 (1985).

35. The lower the rank of the offending individual, the greater the number of superiors there are who may impose summary non-judicial punishments under UCMJ Art. 15, 10 U.S.C. 815 (1982). See AIR Force Judge Advocate General School, Militara Justice Deskbook 93-97 (1984) (describing authority of officers of various ranks to impose summary punishment). In addition, lower ranking personnel tend to have fewer resources with which to defend themselves against disciplinary action, including peer sympathy of the officers sitting on courts-martial and influence within the hierarchy. High-ranking officers can sometimes exert control over investigations into their own misconduct. See For Admiral, Warning; for G.I.'s, Jail, N.Y. Times, Feb. 16, 1985, § 1, at 5, col.3 (lowerranking servicemen court-martialed and imprisoned "at hard labor" for smuggling captured enemy weapons from Grenada to U.S., but admiral given nonpunitive warning for same offense after heading off investigation).

36. The military's zeal to deter conduct deviating from its own norms has never been in doubt. Indeed, the UCMJ was an attempt to "civilianize" military justice and lessen the ferocity with which such deviations were punished. Sherman, The Civilianization of Military Law, 22 ME. L. Rev. 3, 15-29, 59 (1970). Despite the "civilianization," the UCMJ includes offenses that are based on disloyalty or non-conformity to exclusively military norms.. See Art. 88 (uttering contemptuous words against government officials), Art. 89 (disrespect to superior officer), Art. 133 (conduct unbecoming an officer), Art. 134 (conduct "to the prejudice of good order and discipline" or of such a nature as to bring discredit upon the armed forces), 10 U.S.C. $\$ \S 888,889,933,934$ (1982).

37. See Brown v. United States, 739 F.2d 362 (8th Cir. 1984) (no disciplinary action taken 
tary remedies seem equipped to deal with more isolated instances of conduct that egregiously violates civilian but not military norms, such as use of troops for experimentation, ${ }^{38}$ or the suppression of dissenting views. ${ }^{39}$ In general, the effectiveness of intramilitary remedies in deterring military misconduct is limited by the fact that the military does not view its justice

against racially motivated "mock lynching" of black national guard trainee by fellow guardsmen); Stubbs v. United States, 744 F.2d 58, 61 (8th Cir. 1984) (female soldier, who committed suicide after being sexually assaulted by her drill sergeant, believed that superior officers would not respond to her grievance but would brand her a troublemaker); Brief for Respondents at 2-3, Chappell v. Wallace, 462 U.S. 296 (1983) (ship's captain and junior officers, who allegedly prevented black sailors' placement in skilled work positions and gave out punishments and low performance ratings on racial grounds, also allegedly failed to identify and discipline sailors who put KKK graffiti and noose in black sailor's work space). See also United States v. Hullum, 15 M.J. 261, 264-65 (C.M.A. 1983) (black sailor, who absented himself after receiving death threats from shipmates and unsuccessfully seeking help from superior officers, had arguable duress defense to court-martial charges of unauthorized absence); United States v. Roberts and Sutek, 14 M.J. 671, 673 (N.M.C.M.R. 1982) (courtmartial charges of unauthorized absence against female sailor dismissed on defense of duress because sailor had been subjected to physical and verbal sexual harrassment, reasonably feared serious bodily injury from shipmates, and had unsuccessfully complained to superior officers).

Race relations in the armed forces have improved somewhat since reaching a crisis point during the Vietnam war, when dozens of incidents of race-related violence took place on military bases and ships at sea. See Brief for Respondents at 32-35, Chappell v. Wallace, 462 U.S. 296 (1983). At Camp LeJeune, North Carolina, a Marine Corps basic training camp, 160 assaults, muggings and robberies with racial overtones took place in the first seven months of 1969. D. Zlllman, A. Blaustrin, E. Sherman, D. Faw, M. Larkin, J. Munster, J. Paust, R. Peckham \& A. Rakas, The MinjTARY IN AMERICAN SOcIETY \$ 4.09 at 4-95 (1977) [hereinafter cited as D. Zilliman, A. BLAUSTEIN, E. ShERman]. Responding to this outbreak, the Marine Corps appointed an investigating committee, which reported: "In the opinion of the black marine, he has no official channel available to him by and through which he can obtain redress for complaints of discrimination." N.Y. Times, Aug. 10, 1969, p. 67, col. 5. In 1973, the Army and Air Force established "Race Relations Councils" and "Equal Opportunity Staff Officers" for the airing of grievances. But "with the air of crisis gone, the effectiveness of the race relations efforts depends considerably upon the interest and tolerance of the commander." D. Zillman, A. Blaustein, E. Sherman, supra, $\S 4.09$ at 4-100-4-101. Gender relations, too, are left largely to the discretion of the commander. See, e.g., United States v. Moorer, 15 M.J. 520, 522-23 (noting base commander's policy prohibiting "use of rank or supervisory position to intimidate or take advantage of soldier in a training status for personal sexual gratification regardless of the knowledge or consent of the individual involved").

38. For example, ordering troops into training exercises to test the effects of nuclear weapons on soldiers' combat performance, see supra note 16 , or using unwitting volunteers to test the effects of LSD, see Stanley v. United States, 574 F. Supp. 474 (S.D. Fla. 1983); Bishop v. United States, 574 F. Supp. 66 (D.D.C. 1983), may not appear different, from a military point of view, from any other dangerous training exercise, such as "live fire" training, or testing of new equipment. But under civilian standards of informed consent, the radiation and LSD tests are involuntary human experimentation, not unlike the actions which the Nuremberg Trials held to give rise to criminal liability despite defenses of military necessity and obedience to superior orders. See United States v. Brandt, in 2 Trials of War Criminals Before tHe Nuernberg Miltary Tribunals 1-12, 174-84 (1947).

39. In particular, service members' adherence to the norms of open public debate is sometimes taken by insiders as disloyalty to the military and punished by lawless reprisals. See, e.g., Sigler v. LeVan, 485 F. Supp. 185 (D.Md. 1980) (Army counterintelligence agent planning to write memoirs found dead in motel room after Army intelligence, CIA and FBI agents allegedly interrogated him there for nine days and extorted his papers and effects from his wife); Mollnow v. Carlton, 716 F.2d 627 (9th Cir. 1983) (Air Force officer, whose repeated warnings about unsafe operation of jet aircraft were ignored by superiors, alleged that his superiors, embarrassed when jet plane did crash, suppressed his reports and grievances and conspired to drive him out of Air Force). Cf. Nixon v. Fitzgerald, 457 U.S. 731 (1982); Harlow v. Fitzgerald, 457 U.S. 800 (1982) (Air Force civilian "whistleblower" allegedly removed from job illegally by White House aides for "disloyalty"). 
system or grievance procedure as a way of deterring misconduct defined by civilian norms. ${ }^{40}$

The Feres doctrine's failure to distinguish between negligent and intentional or constitutional torts has allowed courts applying the doctrine to gloss over the possible inadequacies of intramilitary remedies. Torts that are "merely" negligent may often involve more serious physical injuries

40. Court-martial practice bears this out to some extent. In "civilianizing" military justice, Congress has always shown great concern for the problem of "command influence": an officer's abuse of authority to influence a court-martial proceeding. See H. MOYER, JUSTICE AND THE MILITARY § 3100 , at 677-78 (1972) (defining "command influence); id. § 3-111, at 684-85 (recounting congressional debate on command influence from 1950 to $1970 \mathrm{~s}$ ). Command influence symoblizes a confrontation of military preferences for hierarchical control and summary discipline with a civilian conception of "due process." Although command influence remains a pervasive problem, the military has not sought to deter it by using the established sanction of Article 98, 10 U.S.C. $\$ 898$ (1982) (failure to adhere to other UCMJ provisions, or to interfere with court-martial process is itself a court-martial offense). Since the UCMJ's inception in 1950, there has not been a single prosecution for unlawful comand influence. Telephone interview with Robert S. Rivkin, court-martial defense attorney (March 13,1986 ). See H. MOYER, supra, § 3-340, at 776 (Art. 98 "is a dead letter"). Instead, command influence is treated as a procedural defect, raised on behalf of court-martial defendants. See, e.g., United States v. Berry, 39 C.M.R. 541 (1968).

This pattern of implementing the ban on command influence suggests a split between the command-level practice, on the one hand, and the principle imposed by military appellate judges and policy-makers on the other. The racial and sexual harrassment cases that filter up to the military and civilian appellate courts suggest a similar pattern. An aggrieved service member unsuccessfully seeks redress from his or her commander and then engages in an act of self-help, such as unauthorized absence. As a result, court-martial charges are brought; and it is only at the level of military appellate courts that the initial unremedied grievance is recognized. See United States v. Hullum, 15 M.J. 261, 264-65 (1983) (black sailor, who absented himself after receiving death threats from shipmates and unsuccessfully seeking help from superior officers, had arguable duress defense to court-martial charges of unauthorized absence); United States v. Roberts and Sutek, 14 M.J. 671, 673 (1982) (court-martial charges of unauthorized absence against female sailor dismissed on defense of duress because sailor had been subjected to physical and verbal sexual harrassment, and reasonably feared serious bodily harm from shipmates, and had unsuccessfully complained to superior officers). This pattern suggests, as in the command influence example, that while high-ranking military officials and judges are more than willing to set policies and precedents favorable to the integration of women and minorities, command level officers nevertheless have a great deal of discretion under such regulations. These latter officers may be less committed to resolving race and gender problems, yet they, for the most part, control the grievance procedure. See generally R. Rivkin \& B. STICHMaN, The Rights of Military Personnel 129 (1977) (commanding officers tend to ignore regulations on racial discrimination).

Finally, the service person's grievance procedure is a highly implausible vehicle for pressing a controversial grievance. Article 138 grievances are passed up through the chain of command, with no time limit or sanction for delay; any of the officers passing on the complaint may stall with relative impunity. See Dep't of the Army Regulation AR 27-14 (1979); H. MoYer, supra § 6-234, at 1207-08. Moreover, the soldier's exercise of the right to complain can sometimes lead to adverse disciplinary action. See, e.g., United States v. Wolfson, 36 C.M.R. 722 (1966); United States v. Schmidt, 16 C.M.A. 57, 36 C.M.R. 213 (1966). In Wolfson, a drafted doctor serving in Vietnam was charged and convicted of conduct unbecoming an officer and gentleman when, after a period of frequent complaints about his duty assignment to Vietnam and the unavailability of surgical supplies, he finally presented his grievance in person to the Vietnam Commander, General William Westmoreland. A divided court of Military review noted that the complaints were "emotional and immature . . . ill advised . . . illtimed, indiscreet and impolitic" but reversed the conviction nevertheless. In Schmidt, an enlisted man who had threatened to send the story of his grievance to a local newspaper, was charged with and convicted of extortion and wrongful communication of threat; but the military appellate court overturned the conviction. These cases suggest, again, that military appellate principles may differ from those of command level officers. 
than torts that can be characterized as intentional or constitutional. But negligent torts are distinguished by the absence of norm-violating behavior, and the military's interest in efficiently performing its function creates incentives to discipline negligent conduct-from the careless mainteriance personnel responsible for a barracks fire to the foolhardy officer who orders his troops into an untenable combat situation-through internal channels. ${ }^{11}$ Intentional or constitutional torts offend societal norms in a way that deserves moral condemnation, and an action for damages is a way to vindicate these norms, as well as to compensate the victim. ${ }^{42}$ The military justice system can be expected to fulfill this function by imposing administrative or criminal sanctions only where its norms and interests accord with civilian ones.

\section{Institutional Competence of Civilian Remedies}

The judiciary's long-standing deference to the military's requirements for discipline reflects a lack of faith in its own institutional competence: Courts consider themselves unable to evaluate what military discipline requires, and in particular, what adverse impact various judicial "intrusions" might have."3 But this concern for discipline does not demand the Feres doctrine's complete abdication, in the intramilitary context, of the judiciary's proper role in remedying torts of government officials.

\section{A. Judicial Intrusion into Military Discipline}

Courts have justified the Feres doctrine as necessary to avoid the intrusion into military discipline caused by a full civilian adjudication of intramilitary tort claims. What courts have meant by "discipline" is really a combination of three different concerns. ${ }^{44}$

41. See, e.g., UCMJ Art. 109, 10 U.S.C. $§ 909$ (punishing negligent damage to military property).

42. See Harlow v. Fitzgerald, 457 U.S. 800, 814 (1982) ("In situations of abuse of office, an action for damages may offer the only realistic avenue for vindication of constitutional guarantees."); Calabresi \& Melamed, Property Rules, Liability Rules and Alienability: One View of the Cathedral, 85 HARv. L. REv. 1089, 1126 \& n.71 (1972) (punitive damages analogized to criminal sanctions).

43. See, e.g., Chappell v. Wallace, 462 U.S. at 300-02; United States v. Brown, 348 U.S. 110, 112 (1954).

44. Courts have also expressed anxiety over the potentially great volume of intramilitary tort litigation. Even without the Feres doctrine, however, courts could dispose of frivolous suits on summary judgment. See Butz v. Economou, 438 U.S. 478, 507-09 (1978). Moreover, the alarm about "floods of litigation" in the tort setting reflects an extremely narrow view: The potential volume of tort litigation often reflects an underlying social problem in need of redress, particularly where plaintiffs persist in bringing suits in the face of procedural obstacles. See Zacharias, The Politics of Torts, 95 YALE L.J. 698, 726 (1986). Even where a legislative solution may, in the long run, be more efficient or "institutionally competent," the removal by courts of a judge-made immunity rule may still be necessary to prod legislators into action. See id. at 728-29; infra note 71. 


\section{Causing Disruption through Factual Inquiries}

Military officials would no doubt prefer that their decisions and actions be completely shielded from civilian review. ${ }^{45}$ Such civilian review can cause embarrassment to the military, and harm its prestige; ${ }^{48}$ it can bring to light, heighten or even create dissension within the ranks; and these consequences can chill vigorous decisionmaking." The prospect of "second guessing military orders, and [requiring] members of the Armed Forces to testify as to one anothers' decisions and actions" 48 can thus threaten the military's reputation and internal loyalty and unity.

But these interests in themselves provide a dubious basis for barring civilian factual inquiries, because there is a recognized public interest in having a military establishment that is not entirely closed, monolithic and secretive. ${ }^{49}$ Moreover, these interests have not been deemed strong enough

45. "Civilian" review should be taken to refer to oversight by the legislative and judicial branches of government and the general public. Civilian officials of defense agencies within the executive branch are better thought of as members of the military organization for the purposes of this Note because institutional pressures within the military establishment have tended to "militarize" civilian officials, who cannot be relied upon to impose democratic checks on the military's influence over public policy. A. Yarmolinsky, The Militrary Establishment 83-84 (1971); Pilisuk \& Hayden, Is There a Military-Industrial Complex which Prevents Peace? in The Bias of Pluralism 123 (W. Connolly ed. 1969).

46. The related problem of risk to security can be alleviated by judicious use of privileges, in camera inspections and the like. See Sigler v. LeVan, 485 F. Supp. 185, 198-99 (D.Md. 1980) (rejecting defendant's argument that litigation would compromise national security).

47. See infra text accompanying notes 53-57. The chilling effect of potential embarrassment through civilian factual inquiries should not be overemphasized, however. First, it is far from clear that disclosures at a civilian tribunal can bring greater dishonor upon a military officer than disclosures at a military tribunal, since a military officer may well place greater value on the judgment of his military peers than on that of a civilian judge and jury. Second, intramilitary inquiries and courtsmartial are not necessarily shielded from civilian scrutiny anyway. Soldiers may be represented at court-martial proceedings by civilian lawyers. United States v. Jorge, 23 C.M.A. 580, 50 C.M.R. 845 (1975); United States v. Donohew, 18 C.M.A. 149, 39 C.M.R. 149 (1969). Court-martial proceedings must be open to the public, unless classified information would be disclosed. COMMITTEE FOR Legal Research on the Draft, Basic Resource Materials on Military Law 55 (3rd ed. 1971). During the court-martial of Army doctor Howard Levy during the Vietnam War, the defendant's civilian lawyer made frequent recourse to the local and national press. See R. SHERRILL, MILITARY Justice is to Justrce as Military MUSIC is To Music 148 (1970). Still, military authorities can often, in practice, exercise control over investigations or court-martial proceedings to limit the potential for embarrassment.

48. Stencel Aero Engineering Corp. v. United States, 431 U.S. 666, 673 (1977).

49. Cf. New York Times Co. v. United States, 403 U.S. 713, 717 (1971) (Black, J., concurring) (duty of press to "expose deception in government" in order to "prevent any part of the government from deceiving the people and sending them off to distant lands to die of foreign fevers and foreign shot and shell"). Investigations into military or other executive affairs by Congress or the press are vital to the political process. Also, rivalry within and between branches of the military has been valued for enhancing civilian control, in part by providing competing sources of information that generate alternatives for civilian policymakers. See A. KANTER, DefEnSE Politics 24 (1975); see also A. Yarmolinsky \& G. Foster, Paradoxes of Power: the Military Establishment in THE EIGHTIES 97 (1983) (Joint Chiefs of Staff purposely set up so as to protect autonomy of military branches from centralized control, and chiefs encouraged to report individually to Congress). Occasional embarrassment to the military in the arena of politics can be justified as necessary to the ability of Congress to fulfill its constitutional role of military policymaking. Although the judiciary is not charged with the same active oversight of executive branch affairs, it is far from clear that the interest 
to foreclose haling military officers into court when the plaintiff was other than an intramilitary tort victim. ${ }^{50}$ Civilian plaintiffs are not barred from bringing suit for injuries caused by the tortious conduct of the military, even though servicemen injured in the same incident would be barred from suing under Feres. ${ }^{62}$ In cases involving civilian plaintiffs, the extent of factual inquiries into military affairs does not appear to be substantially less than in cases involving military plaintiffs.

\section{Chilling Decisionmaking by Damage Remedies}

Vigorous decisionmaking and execution of military activities represents an important societal interest that can conflict with the interest in deterring overzealous conduct by military officers. The prospect of intramilitary damage remedies could chill vigorous decisionmaking at all levels of command. However, the public interest in protecting decisionmaking processes varies with the type of decision or function involved. For example, a strategic or tactical decision during wartime may be entitled to the utmost protection from judicial intrusion, ${ }^{\text {s3 }}$ whereas a decision to test the

of an executive agency in avoiding embarrassment justifies immunity from investigation in a judicial proceeding. Cf. United States v. Nixon, 418 U.S. 683, 706-13 (1974) (generalized claim of executive privilege outweighed by interests of compulsory criminal process).

50. General William Westmoreland's multi-million dollar defamation suit against CBS brought high-ranking military officials into court to testify on both sides as to decisions and actions that were highly sensitive, from the point of view of prestige, if not security. See, e.g., Jury Told of Order to Cut Troop Count, N.Y. Times, Feb. 12, 1985 at B6, col. 4; CBS Witness Says General Set Ceiling, N.Y. Times, Feb. 6, 1985, at B4, col. 1; 2 Veterans Testify on Enemy for CBS, N.Y. Times, Feb. 5, 1985, at B3, col. 4. Indeed, Westmoreland claimed to have settled the case because he was disheartened that a colleague, Maj. Gen. Joseph McChristian, had testified against him. The Westmoreland Case: $A$ Broken West Point Tie, N.Y. Times, Feb. 24, 1985, § 1, at 1, col. 3.

51. The language of the FTCA makes explicit that Congress contemplated suits against the military, leaving exceptions to liability for claims "arising out of the combatant activities of the military . . during time of war." 28 U.S.C. \$ 2680(j) (1982); see Feres, 340 U.S. at 138.

52. In Allen v. United States, 588 F. Supp. 247 (D.Utah 1984), the court tried the claims of twenty-four civilian "down wind" residents for injuries due to their exposure to radioactive fallout from the nuclear tests involved in Jaffee. Ten of the twenty-four plaintiffs won damage awards against the government, totaling \$2.4 million, and over a thousand claims are still pending. Allen, 588 F. Supp. at 448. The scope of the litigation is comparable to that presented by the class of servicemen in Jaffee. See also Stencel Aero Engineering Corp v. United States, 431 U.S. 666, 676-77 (1977) (Marshall, J., dissenting) (discussing hypothetical cases in which civilians injured in same factual transaction as military personnel might recover); In re "Agent Orange" Product Liability Litigation, 580 F. Supp. 1242 (E.D.N.Y. 1984) (same). But see, e.g., Hinkie v. United States, 715 F.2d 96, 98 (3d Cir. 1983) (barring Atomic Veterans' children's claims on grounds that "genesis" of children's injury was genetic damage to fathers whose claims were barred by Feres); Lombard v. United States, 690 F.2d 215, 227 (D.C.Cir. 1982) (same); Monaco v. United States, 661 F.2d 129 (9th Cir. 1981), cert. denied, 456 U.S. 989 (1982) (same). The reasoning of these cases has been attacked in In re "Agent Orange" Product Liability Litigation, 580 F. Supp. 1242. In that part of the massive "Agent Orange" litigation, wives of servicemen exposed to Agent Orange claimed that genetic damage to their husbands' sperm from exposure to the chemical caused them to miscarry because they had conceived defective fetuses. The court held that their claims were not barred under the Feres doctrine's protection of defense contractors.

53. See, for example, FTCA exceptions to government liability for "discretionary functions" or "combatant activities," 28 U.S.C. $\$ \S 2680(a) \&(j)$. 
usefulness of LSD for interrogations ${ }^{54}$ or to suppress reports of whistleblowers ${ }^{\mathrm{bs}}$ deserves less protection. But the Feres doctrine indiscriminantly accords the same absolute protection to combat decisions as it does to the decision to commit a sexual assault. ${ }^{56}$ The breadth of claims barred by Feres suggests the need for a particularized inquiry into the military function, or the type of decision, that would be protected. Courts typically undertake such inquiries-weighing the defendant's interest in protecting its decisionmaking-later in the litigation, when considering the defendant's claim for immunity. ${ }^{57}$

\section{Promoting Disobedience of Soldiers}

Courts applying the Feres doctrine have expressed the fear that hearing intramilitary tort claims on the merits would interfere with the special authority relations between military personnel and their superiors, undermining a soldier's habit of obedience to commands. ${ }^{58}$ This proposition implies that lower-ranking personnel would become more likely to challenge or defy orders if they believed they could assert rights that would be enforceable in civilian courts or initiate proceedings that would place their superiors temporarily under civilian control. ${ }^{59}$

Generally speaking, it is true almost by definition that consciousness of one's rights makes any person less inclined to obey authority. But the military does not have a legitimate or recognized interest in the blind obedience of its personnel. ${ }^{60}$ In addition to providing the grievance procedure, military law tries to allow some rights to military personnel, including constitutional rights. $^{61}$ Moreover, military law imposes an obligation on

54. See, e.g., Stanley v. United States, 574 F. Supp. 474 (S.D. Fla. 1983).

55. See Mollnow v. Carlton, 716 F.2d 627 (9th Cir. 1983) (whistleblower's claim barred).

56. See Stubbs v. United States, 744 F.2d 58 (11th Gir. 1984).

57. See infra note 97 .

58. See Chappell v. Wallace, 462 U.S. at 300. But $c f$. Dep't of the Army Regulation AR 600-20 ("Authority will impose its weight by the professional competence of leaders at all echelons rather than by the arbitrary or despotic methods of martinets . .."), quoted in R. Rivikin \& B. STICHMAN, supra note 40, at 123 .

59. This effect on discipline is an empirical question. Conceivably, damage remedies could be available and invoked from time to time without promoting defiance in the ranks. The existence of such damage remedies might actually promote discipline because soldiers could be more confident that obeying orders would not result in undetected harms to them, such as irradiation or ingestion of LSD.

60. Compare Chappell v. Wallace, 462 U.S. at 300 (dictum) ("habit of immediate compliance with military procedures and orders must be virtually reflex with no time for debate or reflection") with United States v. Calley, 22 C.M.A. 534, 541, 48 C.M.R. 19, 26 (1973) ("TT]he obedience of a soldier is not the obedience of an automaton. A soldier is a reasoning agent, obliged to respond, not as a machine, but as a person.").

61. See, e.g., Burns v. Wilson, 346 U.S. 137, 142 (1953) (federal courts have habeas corpus jurisdiction to review all constitutional issues not fully and fairly considered by military tribunals); United States v. Tempia, 16 C.M.A. 629, 37 C.M.R. 249 (1967) (protections in Bill of Rights available to court-martial defendants); United States v. Lange, 14 C.M.A. 486, 35 C.M.R. 458 (1965) (Fourth Amendment prohibits dragnet "shakedown searches" for contraband in private rooms and lockers). 
soldiers to refuse to obey unlawful orders, a duty quite inconsistent with unthinking obedience even to combat commands. ${ }^{62}$ Finally, the military's interest in such strict discipline cannot be the value of discipline for its own sake, or even for the sake of performing the military's wide range of non-combat functions; its interest ultimately lies in the connection between disicpline and combat readiness and effectiveness. Yet combat effectiveness, as a practical matter, is not necessarily correlated with blind obedience to commands. ${ }^{63}$

Military law thus embodies policies that suggest that the need for obedience does not preclude significant rights and remedies against superiors. Federal courts seem implicitly to recognize this principle in their willingness to adjudicate claims of rights outside the tort context. ${ }^{64}$ Such claims, of course, differ substantially in certain respects from tort claims in that they can be resolved without intrusive factual inquiries and decisionchilling remedies. ${ }^{65}$ However, the prospect of non-tort claims can swell a

Fifth amendment rights are embodied in UCMJ Articles 31 (freedom from self-incrimination) and 139 (redress for unlawful taking of or damage to property), 10 U.S.C. $\S \S 831,939$.

62. Soldiers are subject to criminal sanctions for obeying orders to commit war crimes. See United States v. Calley, 22 C.M.A. 534, 541-44, 48 C.M.R. 19, 26-29 (1973) (obedience to superior orders no defense where defendant should have known that order to kill civilians was illegal); United States v. Kinder, 14 C.M.R. 742, 770-73 (1953) (soldier who executed order to shoot subdued prisoner at South Korean airbase could not rely on obedience to superior orders as defense).

63. During World War II, the War Department dispatched Historical Teams to stay close to the front lines and conduct interviews with troops shortly after combat. The data from the thousands of interviews provided the basis for several studies concluding that troops in combat are motivated to fight, rather than break and run, by the near presence of comrades and a desire not to let those comrades down. See S. Marshall, MEN Against FIRE 40-41 (1947); R. Rivkin, GI Rights and Army Justice 336-37 (1970); J. Keegan, The Face of Batrle 72-73 (1976). The norms of hierarchy, leadership, discipline, or fear of court-martial did not figure as important motivators. See R. RIvkin, supra; Howland, The Hands-Off Policy and Intramilitary Torts, 71 IowA L. REv. 93, 115-18 (1985).

64. Since the $1950 \mathrm{~s}$, military personnel have obtained judicial review of court-martial proceedings (through federal habeas corpus jurisdiction), less-than-honorable discharges, refusals to discharge conscientious objectors, and treatment violating either military statutes or regulations, or claimed constitutional rights. See generally Sherman, Legal Inadequacies and Doctrinal Restraints in Controlling the Military, 49 IND. L.J. 539, 560-81 (1974). In addition, the Court of Claims has jurisdiction over claims involving interference with military career advantage, and it may award "liquidated or unliquidated damages in cases not sounding "in tort." " 28 U.S.C. $\$ 1491$ (a)(2) (1982).

65. Non-tort intramilitary claims in civilian courts tend to involve procedural challenges from administrative or court-martial rulings where the federal court takes the facts as given from the military tribunal, compare Parker v. Levy, 417 U.S. 733, 736 (1974) ("The facts upon which [Levy's] conviction rests are virtually undisputed .... Appellee persisted in his refusal to obey the order ...") with R. SHERRILL, supra note 47, at 98-157 (court-martial authority did not allow defendant Levy to raise defense of unlawfulness of orders, so that military could cover up defendant's allegations of war crimes by U.S. special forces in Vietnam); or else purely legal challenges to military statutes or regulations, see, e.g., Brown v. Glines, 444 U.S. 348 (1980) (First Amendment and statutory challenge to military regulation requiring base commanders' approval before solicitation of signatures for petitions); Schlesinger v. Ballard, 419 U.S. 498 (1975) (sex discrimination challenge to statutory promotion and discharge policies); Dronenburg v. Zech, 741 F.2d 1388 (D.C. Cir 1984) (equal protection challenge to military statute proscribing homosexual conduct); Goldman v. Secretary of Defense, 734 F.2d 1531 (D.C. Gir. 1984) (free exercise clause challenge to application of Air Force regulation prohibiting wearing of yarmulke). For general discussions of such legal challenges, see Sherman, 
soldier's sense of his or her rights as much as, if not more than, tort claims. ${ }^{6 \theta}$ Yet courts have never held that military personnel are barred from all redress in civilian courts for wrongs suffered in the military. ${ }^{67}$

\section{B. Judicial Competence-by Default}

In taking the position that federal courts have no role in adjudicating intramilitary tort claims, the Feres decisions have relied heavily on the competence of intramilitary remedies. Indeed, the Court in Chappell implied that because Congress has "plenary constitutional authority over the military," congressional creation of intramilitary remedies precludes the judiciary from reviewing any intramilitary damage claims. ${ }^{68}$ The implication that courts have no proper role in this field is misleading and inconsistent with the Supreme Court's fashioning of public tort law. ${ }^{69}$

supra note 64; Note, Judicial Review of Constitutional Claims Against the Military, 84 Colum. L.REv. 387 (1984).

66. Arguably, the right to press tort claims is far more dangerous than the right to challenge administrative matters, because the former might affect obedience to a combat command. But such an objection is addressed by the proposal of this Note, which would not allow active-duty service members to sue or alter the absolute immunity for officers in combat situations.

67. See Chappell v. Wallace, 462 U.S. at 304 . However, federal courts have usually deferred to the military in deciding the merits of these claims. See, e.g., Brown v. Glines, 444 U.S. 348 (1979) (military's special need for discretion over internal discipline and morale justifies restrictions on First Amendment rights that would be unacceptable in civilian setting); Parker v. Levy, 417 U.S. 733 (1974) (same). Several circuits, following Mindes v. Seaman, 453 F.2d 197 (5th Cir. 1971), have adopted a restrictive justiciability standard that precludes review on the merits where the soldierplaintiff's interest is relatively weak and the military's interest relatively strong. See Note, supra note 65, at 397 n.57. The Supreme Court has not adopted the Mindes approach, however.

68. Chappell v. Wallace, 462 U.S. at 301-02. "Congress, the constitutionally authorized source of authority over the military system of justice, has not provided a damage remedy for claims by military personnel that constitutional rights have been violated by superior officers. Any action to provide a judicial response by way of such a remedy would be plainly inconsistent with Congress' activity in this field." Id. at 304.

69. Part of the confusion arises from the fact that there are two avenues for tort claims against the government. The FTCA is a congressional act that provides a limited waiver of sovereign immunity. Prior to the statute's enactment in 1946, tort claims naming the United States as a party were barred by sovereign immunity-a common law doctrine inherited from English common law-and tort remedies against the United States were only available through private bill legislation by Congress. P. SchuCK, supra note 25, at 37 . Since the passage of the FTCA, a tort claim against the government is based on a statutory cause of action. Thus, in defining the scope of federal government liability in tort, the courts must construe a congressional statute. In interpreting the legislative intent behind the FTCA, the Feres Court used the existing military compensation scheme, not to suggest that congressional activity in the field of intramilitary injury law precluded judicial activity in that field, but rather as evidence to support a particular interpretation of the FTCA: that Congress could not rationally have intended to subject the federal government to various state-law standards of care and measures of recovery for injured soldiers when the military compensation scheme was designed to provide uniform recovery.

The second avenue for tort claims against the government, a Bivens remedy, is a judicially-created, federal common-law remedy, implied directly from the Constitution, and designed to fill a statutory gap where Congress has failed to create adequate statutory remedies for violations of constitutional rights. Congressional intent does enter into a Bivens analysis in that the existence of an alternative, equally effective remedy deemed by Congress to be a substitute for recovery under the Constitution would pre-empt a Bivens remedy. See supra note 20 . Yet the degree of deference that courts owe to congressional intent is arguably less than in construing a statute, because the court in a Bivens analy- 
Bivens and its progeny ${ }^{70}$ suggest a role for the courts in enforcing constitutional norms to deter unconstitutional tortious conduct where Congress has not created adequate remedial structures. The military system of compensation and justice presents such a situation: As an institution, the military is not competent to remedy certain instances of wrongful conduct. ${ }^{71}$

The purpose of deterrence by public tort remedies is to protect the norms of a society governed by civilian law. Although civilian courts may

sis is often interpreting congressional inaction. The Bivens court itself actually appeared to have gone against the implied will of Congress, since the remedy it created-damages for intentional torts committed by law enforcement officials-was at that time explicitly precluded under the FTCA. 28 U.S.C. $\S 2680(h)(1970)$ (amended, Pub. L. No. 95-253, 88 Stat. 50 (1974)). Indeed, the history of public tort law in America has been a story of "extraordinary judicial creativity and chronic legislative neglect." P. Schiuck, supra note 25 , at 53.

70. See supra note 20 .

71. See supra text accompanying notes 31-42.

The case of the Atomic Veterans shows not only the inadequacy of military compensation, see supra note 34, but also legislative neglect. After at least six years of hearings on the subject, Congress has passed only two pieces of legislation aimed at relief of Atomic Veterans. (I do not count the ceremonial proclamation of an "Atomic Veterans Day" in 1983, Pub. L. No. 98-54, 97 Stat. 288 (1983).) The first, Pub. L. No. 97-72, 95 Stat. 1047 (1981) (codified at 38 U.S.C. § 610(a),(e) (1982)), provided that Atomic Veteran cancer victims could be treated at VA hospitals "notwithstanding that there is insufficient medical evidence to conclude that such disability may be [serviceconnected]." This act did not provide for compensation, however, and because the law still allowed the VA to deny medical treatment of non-cancerous illnesses and cancers that the VA felt could affirmatively be identified as not service-related, the act "has proven totally inadequate in meeting the health care needs of atomic veterans." Veterans Exposure Hearing, supra note 16, at 290 (statement of John Smitherman, Pres., Nat. Ass'n of Atomic Veterans). The Veterans' Dioxin and Radiation Exposure Compensation Standards Act, Pub. L. No. 98-542, 98 Stat. 2725 (1984), found that "there is scientific and medical uncertainty regarding [the] long-term adverse health effects," id. at $\S 2$, of ionizing radiation (and "agent orange" exposure) and provided only that the Veterans Administrator "prescribe regulations to . . . establish guidelines and (where appropriate) standards and criteria for the resolution of claims" by Atomic Veterans. Id. at $\$ 5(a)$. Significantly, this act was a watered-down version of the bill reported from the House Committee on Veterans Affairs. Entitled "Agent Orange and Atomic Veterans Relief Act," H.R. 1961, 98th Cong. 2d Sess. (1984) (emphasis added), the bill would have established a presumption of service-connection for all Atomic Veteran cancer cases diagnosed within 20 years after the serviceman's participation in the tests. Current VA regulations provide that diagnosis of chronic illnesses must occur within seven years of discharge from the armed forces, a rule which has blocked many claimants. See 38 C.F.R. $\S 3.109$ (1985). The defeated provisions of H.R. 1961 have been resubmitted as The Atomic Veterans Relief Act of 1985, H.R. 1613, 99th Cong., 1st Sess. (1985).

This legislative history is instructive on intramilitary tort victims' hopes of legislative reform in general. The Atomic Veterans are the victims of a single course of tortious conduct, in which 250,000 were initially affected. They are now represented by two national organizations, the Nat. Ass'n of Radiation Survivors, and the Nat. Ass'n of Atomic Veterans, and additional veterans' groups representing at least 1,300 "agent orange" victims have at times allied with them. Despite the size and organization of this group, they have had extremely limited success in obtaining legislative redress for compensation (the issue of vindication of their rights beyond compensation is not even considered). See also N.Y. Times, Nov. 4, 1984, at A26, col. 1 (discussing passage of Warner Amendment to arms appropriations bill, granting Feres-type immunity from Atomic Veteran suits to nuclear weapons contractors). The Warner Amendment suggests that there is virtually no chance of legislative redress for those affected by individual rather than mass torts. Their ineffectuality before the legislature makes intramilitary tort victims prime candidates for judicial redress. A liberal liability rule in intramilitary tort law could prompt a more satisfactory legislative response. $C f$. Zacharias, supra note 44, at 728-29 (discussing judicial prompting of legislative solutions to private-law torts). 
lack a certain competence, in the sense of knowledge about military discipline, they are generally competent to weigh evidence on issues of great technical complexity, and they are more competent than the military to reach a substantively legitimate outcome in deciding when constitutional rights have been violated..$^{72}$ The issue at the heart of the Feres doctrine is this: In the absence of congressional guidance, ${ }^{73}$ who will balance the military's discipline interest against civilian and constitutional norms-the courts or the military? ? $^{74}$

\section{A Proposal for Federal Court Adjudication of INTRAMILITARY TORT ClLAIMS}

The courts have, in effect, allowed the military to strike this balance. The Feres doctrine presumes both the adequacy of intramilitary remedies and the threat to discipline posed by lawsuits in all intramilitary tort claims. Yet courts could instead fashion a less restrictive rule that takes account of Feres concerns while allowing certain intramilitary claims to go

72. Cf. Orloff v. Willoughby, 345 U.S. 83, 93-94 (1953) ("Orderly government requires that the judiciary be as scrupulous not to interfere with legitimate Army matters as the Army must be scrupulous not to intervene in judicial matters.").

Chief Justice Warren noted the need for increased judicial oversight of the military despite lack of knowledge: "I suppose it cannot be said that the courts of today are more knowledgeable about the requirements of military discipline than the courts in the early days of the Republic. Nevertheless ... [w] hen the authority of the military has such a sweeping capacity for affecting the lives of our citizenry, the wisdom of treating the military establishment as an enclave beyond the reach of the civilian courts almost inevitably is drawn into question." Warren, The Bill of Rights and the Military, 37 N.Y.U. L. REV. 181, 187-88 (1962) (footnotes omitted).

73. There is, of course, some ambiguity as to whether Congress has "spoken" on the issue of intramilitary tort liability. Conceivably, the UCMJ, and Article 138 in particular, should suffice as a normative remedy for constitutional torts. But, in its operation, if not its language, Article 138 is essentially a broad grant of discretion to individual military commanders (who have authority over the complained-of commander) to grant ad hoc remedies. It is not a remedy specially tailored to constitutional torts in the way the civil service remedy in Bush $v$. Lucas was "constructed step by step with careful attention to conflicting policy considerations," and therefore an adequate substitute for a Bivens remedy. 462 U.S. at 388. See supra note 23.

74. The Constitution vests in Congress the authority "[t]o make Rules for the Government and Regulation of the land and naval Forces," art. I, $\S 8, \mathrm{cl}$. 14, and makes the president Commander-inChief of the armed forces, Art. II, § 2, cl. 1. Arguably-and the Chappell court implies just this argument-these provisions are adequate to ensure control of the military by civilian constitutional norms. But such an argument is seriously flawed.

Congressional rulemaking authority over the armed forces' internal justice system usually amounts to grants of discretion to the executive or the military itself. For example, punishments for courtmartial offenses are left indeterminate by the UCMJ and are set by the executive-promulgated Manual for Courts Martial. Also, certain court-martial offenses are themselves worded with extreme vagueness by congressional statute. See, e.g., 10 U.S.C. $\$ 933$ (1983) ("conduct unbecoming an officer and a gentleman" punishable by court-martial); see also Parker v. Levy, 417 U.S. 733, 773-83 (1974) (Stewart, J., dissenting) (attacking 10 U.S.C. $\$ 933$ for vagueness and overbreadth). Executive branch civilians do not necessarily impose the rule of the Constitution on the military either. See supra note 45.

Bivens and its progeny address these arguments squarely. The FBI is a civilian executive agency under the rulemaking authority of Congress. Even so, the Bivens court held damages to be an appropriate remedy for citizens whose constitutional rights had been violated by FBI agents. 
forward. ${ }^{75}$ Such a rule can easily be fit into the existing system of civilian public tort remedies.

\section{A. A Less Restrictive Substitute for the Feres Doctrine}

The foregoing analysis suggests that two considerations are involved in deciding whether a civilian adjudication of intramilitary tort claims should be undertaken: how well the intramilitary remedial system would function by itself to resolve a particular claim; ${ }^{76}$ and how discipline in particular might be affected by a given claim. ${ }^{77}$ I have argued that intramilitary remedies are least able to redress intentional or constitutional tort claims ${ }^{78}$ and that the military's discipline interest in barring intramilitary tort causes of action is clearest when soldiers' obedience to commands is at stake. $^{79}$ These arguments imply a rule that allows intramilitary tort claims where 1) the plaintiff alleges more than simple negligence (an intentional or constitutional tort) ${ }^{80}$ and 2) the plaintiff is not an active duty

75. The Eighth Circuit has developed a "refined" analytical framework to apply to Feres doctrine cases. Besides looking at the duty status of the plaintiff, the court also asks whether the tortious activity "served some military purpose or mission" and whether the trial would question an interaction between officer and subordinate. Brown v. United States, 739 F.2d 362, 367-69 (8th Cir. 1984). In Brown, a black national guard trainee was subjected to a "mock lynching" by several fellow guardsmen, who tied a rope around his neck and actually lifted him off the ground by the rope before releasing him. The victim subsequently went into a deep depression and finally shot himself in the head, causing severe and permanent damage. His lawsuit was allowed on the ground that his assailants were of the same rank; had his superiors been responsible, his claim would have been dismissed under this "refined" test. See also Stubbs v. United States, 744 F.2d 58 (11th Cir. 1984) (no cause of action for surviving family of female private who committed suicide after being sexually assaulted by drill sergeant because command relationship was involved). Thus, this "refined" test completely fails to address the problem of intentional torts committed by persons exploiting a command relationship.

76. A threshold determination concerning the adequacy of intramilitary remedies would have to be made as a matter of law, as the Feres court arguably seems to have done. See 340 U.S. at 144-45 (approving system of "simple, certain and uniform compensation for injuries or death of those in the armed services"). To base a determination of adequacy instead on a factual finding of failure of intramilitary remedies would require judicial review of intramilitary determinations. But courts have been reluctant to review the adequacy of Article 138 grievance decisions, and VA determinations are not judicially reviewable on factual grounds. 38 U.S.C. \$ 211(a) (1982) (barring review on law or fact); see Johnson v. Robison, 415 U.S. 361 (1974) (prohibition of judicial review of VA determinations of fact or administrative law does not bar constitutional challenge to statute). The proposal advanced in this Note obviates the need for a case-by-case judicial inquiry into the adequacy of intramilitary determinations. See infra text accompanying notes 84-90.

77. The Feres doctrine implicitly takes these considerations into account with its "incident-toservice" test, which uses the plaintiffs duty status as a proxy for a particularized inquiry into both the adequacy of intramilitary remedies and the strength of the military's discipline interest. The "incident-to-service" issue has been litigated by many plaintiffs seeking to avoid the Feres bar, but has been resolved in the plaintiff's favor in only a handful of negligence claims. See Zillman, Intramilitary Tort Law: Incidence to Service Meets Constitutional Tort, 60 N.C. L. REv. 489, 511 (1980) (in only 8 of 147 cases litigating "incident-to-service" issue have plaintiffs avoided dismissal under Feres).

78. See supra text accompanying notes $37-42$.

79. See supra text accompanying notes 58-67.

80. This should be understood to include such formulations as "willful," "wanton" or "reckless" negligence. See W. Keeton, D. Dobbs, R. Keeton \& D. OWen, Prosser and Keeton on the LAW OF TORTS 212-13 (5th ed. 1984). 
service member. ${ }^{81}$ Claims of simple negligence or medical malpractice ${ }^{82}$ would be dismissed at the pleading stage, ${ }^{33}$ as would claims by active military personnel or by former military personnel alleging injuries whose effects did not last beyond discharge from the military.

The advantage of this approach is that it screens out insubstantial cases while showing a measure of deference to intramilitary remedies and to the military's interest in the obedience of active-duty personnel. ${ }^{84}$ In order to bring a tort action, an ex-soldier would have to allege a harm that was so serious that its effects were still felt after his or her discharge from the military. ${ }^{85}$ The actual operation of internal military investigations would not be impugned by judicial factual review, because the Article 138 grievance procedure is not available to former soldiers ${ }^{\mathbf{8 B}}$ or civilian family members. Nor would the adequacy of veterans' compensation be explicitly challenged. The intentional or constitutional tort requirement of the proposed rule operates, like the Feres doctrine, as a proxy for particularized inquiry into the adequacy of intramilitary remedies, because it assumes those remedies to be adequate for active-duty personnel, but not for others. But unlike the Feres doctrine, this rule recognizes that intramilitary remedies cannot be expected to serve the public tort law interest in compensation and deterrence when serious misconduct is alleged.

Under my proposal, the military would retain control over resolution of the range of claims whose effects are contained within the duration of military service. ${ }^{87}$ On the other hand, intramilitary claims alleging harms

81. This formulation includes survivors of deceased military personnel, as well as family members who can allege harms to themselves that have their "genesis" in intramilitary tort. See cases cited supra note 17.

82. See, e.g., Feres, 340 U.S. 135; Jefferson v. United States, 178 F.2d 518 (4th Cir. 1949).

83. Thus, Feres, limited to its original facts, need not be overruled.

84. See supra text accompanying notes 58-67

85. The statute of limitations should not begin to run until discharge from the military, because only then would an intramilitary tort victim have a cause of action under the proposal. However, in cases such as Jaffe and Thornwell v. United States, 471 F. Supp. 344 (D.D.C. 1979), where the government allegedly concealed its wrongdoing, the statute of limitations should be tolled further, until the victim discovers (or should have discovered) that he or she has been harmed by military superiors. See Note, Citizen Trust and Government Cover-up: Refining the Doctrine of Fraudulent Concealment, 95 YALE L.J. (forthcoming, June, 1986) (government's superior power and information and public interest in trusting government justify lenient statute of limitations period for citizen tortplaintiffs where government has concealed wrongdoing).

86. See Dep't of the Army Regulation AR 27-14, ๆा 1-2(a), 3-2(3)(a) (Art. 138 complainant must be on active duty in federal service); see also Colson v. Bradley, 477 F.2d 639 (8th Cir. 1973) (Art. 138 remedy, normally unavailable to non-military personnel, would not be denied plaintiff whose grievance was his wrongful discharge from military); Rasmussen v. Seamans, 432 F.2d 346 (10th Cir. 1970) (Art. 138 not available to Colorado Air National Guard member not on active duty in federal service).

87. See, e.g., Tigue v. Swaim, 585 F.2d 909 (8th Cir. 1978) (affirming summary judgment for military defendant). In Tigue, the plaintiff alleged that he had been subjected to a retaliatory psychiatric evaluation which resulted in his removal from his post and confinement in a mental ward for twenty-two days. However, he was subsequently given a favorable psychiatric report, which intimated that he had been subjected to retaliation, and he was promptly restored to his former status. Id. at 
which have a profound, long-term impact on the victims' lives would be actionable. ${ }^{88}$ Moreover, the "habit of obedience" of active-duty personnel is less likely to be affected by extending a right of action to ex-soldiers and family members. ${ }^{89}$ Finally, this approach is consistent with the principle, recognized by the federal courts, that the strictures that military authority places on the citizen-soldier should be limited both to the time and to the sphere in which the citizen actually serves as soldier..$^{90}$

912. Tigue presents a clear case of injury that is contained within the plaintiff's term and sphere of service.

88. Like any reform, the one proposed here is not perfect. As the price of deference to military discipline, it would continue to deny active duty service members civilian redress for present harms while they are still in the service. And it would at times permit sanctions even where the intramilitary justice system may also have imposed sanctions; though the prospect of "double" sanctions would be reduced as the deterrent effect of civil damage remedies modified military behavior. On balance, these problems are outweighed by the benefits of allowing remedies for more egregious cases of intramilitary tort while maintaining deference to military needs for discipline.

89. See In re “Agent Orange" Product Liability Litigation, 580 F. Supp. 1242, 1250 (E.D.N.Y. 1984) ("The fact that an officer might refrain from giving an order to the soldier because a civilian might ultimately sue the United States is so ephemeral and far-fetched that it is given no weight at all in determining the limits of Feres.").

90. The "incident-to-service" rule seems to acknowledge the necessity of limiting military authority to active service. Thus, in Brooks v. United States, 337 U.S. 49 (1949), two active-duty servicemen on furlough were allowed to sue the United States after an army truck collided with their car on a public highway. See also, United States v. Brown, 348 U.S. 110 (1954) (former servicemen allowed to sue United States for post-discharge negligence of army doctors); Thornwell v. United States, $471 \mathrm{~F}$. Supp. 344 (D.D.C. 1979) (same). In Brown, the case that introduced the "discipline" rationale into the Feres doctrine, "the peculiar and special relationship" between soldiers and the military ceased with civilian status. 348 U.S. at 112. Cf. O'Callahan v. Parker, 395 U.S. 258 (1969) (soldier's peacetime criminal act outside of military base subject to trial and punishment by civilian and not military criminal process); Harmon v. Brucker, 355 U.S. 579 (1958) (per curiam) (army not allowed to issue less-than-honorable discharges on basis of alleged pre-service subversive political activities); Stapp v. Resor, 314 F. Supp. 475 (S.D.N.Y. 1970) (same). See generally Sherman, supra note 64, at 574-80 (citing Vietnam era cases of judicial review of induction and discharge).

The Brown principle holds the government liable for post-discharge negligence in following up service-related injuries. This rule has caused a curious development in circuit court decisions on Atomic Veterans' litigation. Some federal courts have recently allowed FTCA claims against the government for a separate, post-discharge tort of negligent failure to warn servicemen of their exposure to radiation, while at the same time holding that Feres required dismissal of related claims of exposure to radiation and failure to warn the serviceman while he was still in the service. See Cole v. United States, 755 F.2d 873 (11th Cir. 1985); Molsbergen v. United States, 757 F.2d 1016 (9th Cir. 1985); Broudy v. United States, 661 F.2d 125 (9th Gir. 1981) ("Broudy I"); Broudy v. United States, 722 F.2d 566 (9th Cir. 1985) ("Broudy II"); Seveny v. United States, 530 F. Supp. 653, 660 (D.R.I. 1982). The litigation has thus been allowed to proceed to the next stage of FTCA inquiry-whether the relationship between the government and the serviceman would give rise to state law liability for failure to warn under analogous circumstances between private parties. See Molsbergen, 757 F.2d at 1020; Cole, 755 F.2d at 878; FTCA, 28 U.S.C. $\$ \S 2674,1346($ b) (1982) (parallel liability and local law requirements). See also supra notes 10-13 and accompanying text (discussing these FTCA provisions). The Molsbergen court actually went so far as to find that California law would hold employers liable for failure to warn a discharged employee of exposure to dangerous substances. 757 F.2d at 1021-24.

The crucial issue in these cases becomes the time at which the government learned of the dangers of radiation exposure, because the duty to warn arises from knowledge of the danger. If the government learned of the danger while the victim was still in the service, the duty would have originated while the injured serviceman was still in the armed forces, and a claim based on negligent failure to warn would be barred under Feres. Cole, 755 F.2d at 876-77; see Heilman v. United States, 731 F.2d 1104 (3d Cir. 1984); Gaspard v. United States, 713 F.2d 1097 (5th Cir. 1983); Lombard v. United States, 


\section{B. Public Tort Law Context}

Under the existing remedial system, citizens may sue federal officials for tortious conduct under Bivens v. Six Unknown Named Agents ${ }^{91}$ or sue the government under the Federal Tort Claims Act. ${ }^{82}$ But the FTGA, without amendment, does not lend itself to an interpretation that would allow suits for intentional torts committed by parties other than law enforcement officials. ${ }^{93}$ At present, the FTCA is "a niggardly waiver of federal governmental immunity," full of qualifications and exceptions. ${ }^{\text {"4 }}$ Indeed, the inadequacies of the FTCA as a remedy to compensate and deter harms arising from a constitutional tort led the Supreme Court in Carl-

690 F.2d 215 (D.C. Cir. 1982); Laswell v. Brown, 683 F.2d 281 (8th Cir. 1982). But if the government learned of the danger, and thus incurred the duty, after the serviceman's discharge, then it would be liable under the FTCA to the serviceman and his surviving family for negligent failure to warn.

This curious line of decisions may be the result of judges' discomfort with the rigid unfairness of Feres. In other areas of tort law, courts have accepted some doctrinal confusion in order to let particularly deserving plaintiffs prevail. See Zacharias, supra note 44 , at 716-24. But this particular doctrinal confusion underscores problems not only inherent in the Feres doctrine, but in the FTCA as well. First, and most obviously, this line of cases holds that the government would be free from liability if it had known the extent of radiation hazards when it subjected servicemen to the tests or shortly after, prior to the servicemen's discharge-precisely the cases in which the government should be most culpable.

Second, because the FTCA excludes liability for intentional torts (with the exception of intentional torts of law enforcement agents), the government could avoid liability by showing that it intentionally failed to warn ex-servicemen of radiation hazards as part of a cover-up-again, a case in which the government is culpable.

Finally, the FTCA scheme imposes potential unfairness on military plaintiffs by subjecting them to various state law standards. While California law, for example, supports liability on a duty to warn theory, Molsbergen, 757 F.2d at 1023-24, Alabama law may not. See Cole, 755 F.2d at 878. The unfairness and irrationality, identified by Feres and its progeny, of subjecting the soldier-government relationship to varying state tort-law standards dependent on where a soldier happens to be stationed, works both ways: Surely, military personnel deserve a uniform standard of care from their government employer, regardless of where the government stations them, because that relationship is "distinctly federal." See supra notes 12-13 and accompanying text. This fairness concern does not support a blanket immunity rule as the Feres court concluded, but rather the application of a federal common law liability rule, such as that found in Bivens and its progeny.

91. 403 U.S. 388 (1971).

92. 28 U.S.C. $\S 2674$ (1982).

93. See P. SCHuck, supra note 25, at 100-22. Certain reforms would be required to open the FTCA to intramilitary intentional tort claims, including: a specific provision extending the government's intentional tort liability; repeal of the state-law tort requirement and extension of government liability to include constitutional torts; and lifting restrictions on attorneys fees and punitive damage awards. Such reforms could make Bivens remedies unnecessary. See id.; Madden, Allard \& Remes, Bedtime for Bivens: Substituting the United States as Defendant in Constitutional Tort Suits, 20 HARV. J. ON LEGIS. 469 (1983).

94. P. Schuck, supra note 25 , at 112-18; see, e.g., "discretionary functions" exception, 28 U.S.C. $\$ 2680$ (a). The doctrinal contortions brought on by this exception are exemplified by Allen v. United States, 588 F. Supp. 247, 338 (D. Utah 1984), which held that the "discretionary functions" exception would have barred claims of civilian radiation victims of nuclear testing only if the government had consciously made a policy decision to use them as "human guinea pigs." However, precisely because the court found that the government's negligent implementation of the testing was not intended to use plaintiffs in that way, the injuries were actionable under FTCA. 
son v. Green ${ }^{95}$ to imply a Bivens remedy even though FTCA recovery was available. Because a Bivens action implicates federal common law, it is not open to the objection, as an intramilitary tort claim under the FTCA would be, that the federal government is subjected to various standards of liability to its military personel. And because a Bivens action must allege the tortious violation of a constitutional right, ${ }^{96}$ the Bivens action might screen out claims less deserving of the level of deterrence generated by damage awards in federal court. Finally, a Bivens remedy would require less modification of existing statute and case-law than would an FTCA approach.97

\section{Conclusion}

Federal courts implementing the Feres doctrine have not necessarily intended that injured service personnel should go uncompensated or that wrongful, tortious conduct should be undeterred. Rather, the Feres decisions have implied that the military compensation system and the military's internal disciplinary and justice procedures can handle these tortlaw functions, and that they do so with a greater sensitivity to the military's institutional needs than civilian courts can. Intramilitary remedies are not, however, adequate across the range of intentional tort claims:

95. 446 U.S. 14 (1980).

96. Federal officials appear to have absolute immunity from state law causes of action, whether statutory or common law. This rule, derived from Barr v. Matteo, 360 U.S. 564 (1958) (plurality opinion) (defamation claim), was not altered by the decision in Butz v. Economou, 438 U.S. 478 (1978) (executive officials must overcome presumption against absolute immunity). See, e.g., Mir v. Fosburg, 646 F.2d 342, 346 (9th Cir. 1980); Granger v. Marek, 583 F.2d 781, 784 (6th Cir. 1978). Under qualified immunity doctrine, federal officials may be stripped of their immunity only for violations of federal statutory or constitutional provisions.

97. To change the Feres doctrine as proposed in this Note via the FTCA requires either legislation or a statutory construction that strains congressional intent. A Bivens remedy is less dependent, jurisprudentially, on the will of Congress. See supra, notes 20,69. Also, to imply a Bivens remedy under the proposal advanced in this Note would not require that Chappell $v$. Wallace be overruled. The Chappell facts do not provide the appropriate grounds for its sweeping holding-precluding (in dicta at least) all Bivens remedies against intramilitary defendants-because the complaint was made by active duty servicemen for harms whose effects may well have been contained within plaintiffs' term of military service. Once a Bivens action is recognized, the court would consider the defendant's entitlement to absolute immunity by making a particularized inquiry into the defendant's functions. See Butz v. Economou, 438 U.S. at 503; Tigue v. Swaim, 585 F.2d 909 (8th Cir. 1978).

In order for the proposal of this Note to be effective, the intramilitary tort cause of action should be coupled with an approach to immunity principles that is liberal to plaintiffs. Absolute immunity could be accorded, for example, only to officials making combat decisions and perhaps to officials whose decisions directly relate to highly sensitive defense matters, such as nuclear weapons maintenance. See Tigue, 585 F.2d 909. This type of line-drawing, it is true, would involve the courts in the very decisions of military expertise that they now purposely avoid under Feres. But the lines can be drawn with varying degrees of deference, with doubts resolved, if necessary, in favor of military immunity. And because judges often weigh evidence of technical experts on subjects about which judges know very little, it would not be out of line to permit military defendants at various stages in the litigation to show that, for example, the challenged decision or action was taken pursuant to a function vital to combat preparedness. 
Due to the internal, institutional pressures to conform or exhibit loyalty in the military, cases involving particularly egregious or widespread military misconduct are more appropriately resolved by civilian courts. In recognizing causes of action by former servicemen and their families for alleged intentional or constitutional torts, courts can show some deference to the concerns underlying the Feres doctrine-the limited adequacy of intramilitary remedies and the military's need to maintain obedience of its personnel-while still allowing public tort remedies for misconduct against citizen-soldiers. 